\title{
Predicting the Profit Growth with Financial Ratio: Study at Real Estate and Property Companies listed in Indonesia Stock Exchange
}

\author{
Rieke Pernamasari ${ }^{1}$, Triyani Budyastuti ${ }^{2}$, Lulu Sagita Putri ${ }^{3}$ \\ \{rieke.pernamasari@mercubuana.ac.id ${ }^{1}$, triyani@mercubuana.ac.id ${ }^{2}$, lulusagitap@gmail.com ${ }^{3}$ \} \\ Universitas Mercu Buana, Indonesia ${ }^{1}$, Universitas Mercu Buana, Indonesia ${ }^{2}$, Universitas Mercu \\ Buana, Indonesia ${ }^{3}$
}

\begin{abstract}
One of the information contained in the financial statements used to determine the success or failure of a company is profit. This study aims to examine the effect of financial ratios in predicting the profit growth.The variables in this study consisted of current ratio (CR), debt to equity ratio (DER), ratio of Total Asset Turnover (TATO) activity, net profit margin ratio (NPM) and profit growth as the dependent variable.The population in this study were real estate and property companies listed on the Indonesia Stock Exchange for the period 2015 - 2017. The samples from this study were 24 companies. Analysis of this study uses a linear regression method consisting of 2 variables, namely the dependent variable and the independent variable. The results showed that Current Ratio (CR), and Debt to Equity Ratio (DER) had no effect in predicting Profit Growth, but Total Asset Turnover (TATO) and Net Profit Margin (NPM) had a positive effect in predicting profit Growth.
\end{abstract}

Keywords: Growth Income, Financial Ratio, Curent Ratio, Debt to Equity Ratio, Total Asset Turnover, Net profit margin.

\section{Introduction}

Business competition in the real estate industry in Indonesia is getting increase. Every real estate company will compete to improve its company. This sector is considered to have an important role in driving the Indonesian economy because it is able to absorb a large number of workers and has a significant impact on chains that attract and encourage other sectors, consequently, real estate and property businesses become increasingly competitive and require companies to adapt to be superior and eminent . (finance.detik.com) (1).

20 emiten property in the first semester of 2017 posted a net profit of around 6.43 trillion during the first six months of this year. This figure increased by $45 \%$ when compared to the acquisition in the same period last year which was IDR 4.41 trillion. The best performance was made by PT Modernland Realty Tbk (MDLN) which managed to score a net profit growth of $902.4 \%$ to Rp 245 billion compared to the first semester of 2016. This growth was in line with $28 \%$ year on year (yoy) revenue growth and accompanied by a decline operating load. (kontan.co.id) (2).

One of the most common company parameters for measuring the increase or decrease in performance in a company is profit. Andayani \& Ardini (2017) say profit is generally used as a measure of a company's achievement so that profits can be used as a basis for investment 
decision making and predictions for forecasting future earnings changes (3). profits obtained by the company for the coming year cannot be ascertained, it is necessary to predict profit growth. Hakim (2013) on luluk and Tiara (2016) Hakim (2013) put forward earnings announcements information that investors use for make decisions on investment activities also projecting or estimating Expectations / expectations of the company in the future will come (4). If management announce rising profits, investors will receive that information financial condition the company is relatively good in the future come. Wait for management approval announces down / low profits, investors will receive that information The financial condition of the company is relatively not good in the future

Profit growth for management is the result of achieving the company's operational activities entrusted to it and related to the survival of the company to always develop. For the government, profit is the basis for calculating corporate income tax. For investors, profit is very important information for making investment decisions. This is related to the estimated amount of cash from dividends to be received, the amount of which depends on the company's future profit (5).

One of the most frequently used financial analysis tools to measure company performance is financial ratios. Septiawan \& Ardini (2017) said financial ratio analysis can be used as an early warning system against the deteriorating financial condition of a company. The ratio used to assess the company's financial performance such as liquidity ratios, leverage ratios, activity ratios and profitability ratios. So the purpose of this study is to find out whether the current ratio, Debt to Equity Ratio (DER), Total Asset Turn Over (TATO, and Net Profit Margin (NPM), has an influence in the growth of profit of a real estate company.

\section{Literature Reviews.}

\subsection{Signalling Theory}

Signal theory was first triggered by Michael Spence (1973) in his research entitled JobMarket Signaling (6). This theory involves two parties, namely an internal party such as management who acts as a party that gives signals and outsiders such as investors who act as the party receiving the signal. Spence said that by giving a signal or signal, the management tried to provide relevant information that could be used by investors. Then, the investor will adjust his decision according to his understanding of the signal. Hakim (2013) suggested that profit announcements contain information used by investors to make decisions on investment activities as well as project or estimate the company's prospects / expectations in the future (7). If management announces rising profits, investors will receive information that the company's financial condition is relatively good in the future. But if management announces lower / lower profits, investors will receive information that the company's financial condition is relatively bad in the future.

\subsection{Profit Growth}

One of the objectives of the company is to obtain profits that will later be able to increase the value of the company and attract many investors to invest in the company. According to Wijayati in Harahap (2011: 267) profit is the difference between the realization of income originating from company transactions in a certain period minus costs incurred to obtain 
income (8). According to Zafira (2016) profit growth is an increase in profits or a decrease in earnings per year. High profit growth indicates the profits obtained by high companies, so the level of dividend distribution is also high (5).

\subsection{Analysis of Financial Ratios}

Definition of financial ratios is a financial report research process and its elements that aim to evaluate and predict the financial condition of the company or business entity and also evaluate the results that have been achieved by the company or business entity in the past and present. Ratio analysis is a form or manner that is commonly used in analyzing the financial statements of a company. By using tools such as ratio analysis will be able to explain or illustrate the analyzer about the good and bad circumstances or financial position of a company (9).

\subsection{Liquidity Ratio}

Liquidity ratio is a ratio that describes the ability of a company to fulfill its short-term obligations. The liquidity ratio can be seen using the current ratio, quick ratio, and cash ratio. In this research using current catio, according to (Bringham \& Houston 2010) dan (Hanafi \& Halim 2014: 75) Current ratio or current ratio is a ratio to measure the company's ability to pay short-term liabilities or debts that are immediately due when billed as a whole (10),(11). In another, The current ratio is stated "The higher the current ratio means the more the company's ability to fulfill short-term financial obligations is large. Assets Current means including cash, receivables, marketable securities, and inventories. From assets smoothly, inventory is current assets that are less liquid than with another. However, if the current ratio is too high it will have a negative effect the ability of profits because some of its working capital does not rotate (12).

\subsection{Leverage Ratio}

Leverage ratio is a ratio used to measure the extent to which a company's assets are financed by debt. Solvability ratio can be measured by Debt to Assets Ratio, Debt to Equity Ratio, Long Term Debt to Equity, Times Interest Earned, Fixed Charged Coverage. In this research using debt to equity ratio is a comparison between the total liabilities held by the company and the total capital sourced from the company (11). The greater the debt to equity ratio shows that the capital structure uses more liabilities than equity.

\subsection{Activity Ratio}

Activity ratio is a ratio to assess a company's ability to carry out daily activities. Activity ratios can be measured by accounts receivable turnover, inventory turnover, working capital turnover, Fixed Assets Turnover, Total Assets Turnover. In this research using total assets turnover is a ratio used to measure the number of times the funds invested in fixed assets revolve in one period (11).

\subsection{Profitability Ratio}


Profitability ratios are the ability of companies to earn profits in relation to sales, total assets, and their own capital. Thus for long-term investors will be very interested in the analysis of profitability. The purpose of profitability is related to the company's ability to obtain satisfactory profits so that investors and shareholders will continue to provide capital for the company (13).

\section{Research Model, Hypotheses, and Methodology}

This research uses quantitative descriptive method that will be associated with existing problems in the object of the research on the influence of financial ratio in predicting the profit growth in real estate company listed in the Indonesia Stock Exchange period 2015 to 2017. The data used in this research were collected from real estate and property company' financial report for the period 2015 to 2017 in the Indonesia Stock Exchange through www.idx.co.id.

Table 1. Sample Selection Procedure

\begin{tabular}{|c|c|c|}
\hline $\begin{array}{c}\text { Ste } \\
p\end{array}$ & Sample Secetion Criteria & $\begin{array}{c}\text { Amoun } \\
t\end{array}$ \\
\hline 1 & $\begin{array}{l}\text { Real estate and Property companies listed on the Stock Exchange in 2015- } \\
2017\end{array}$ & 31 \\
\hline 2 & $\begin{array}{l}\text { Real estate and property company does not generate positive earnings } \\
\text { period } \\
2015-2017 .\end{array}$ & $(7)$ \\
\hline 3 & Number of Samples & 24 \\
\hline 7 & The Number of research samples during 2015-2017 & 72 \\
\hline
\end{tabular}

Source: Data processed

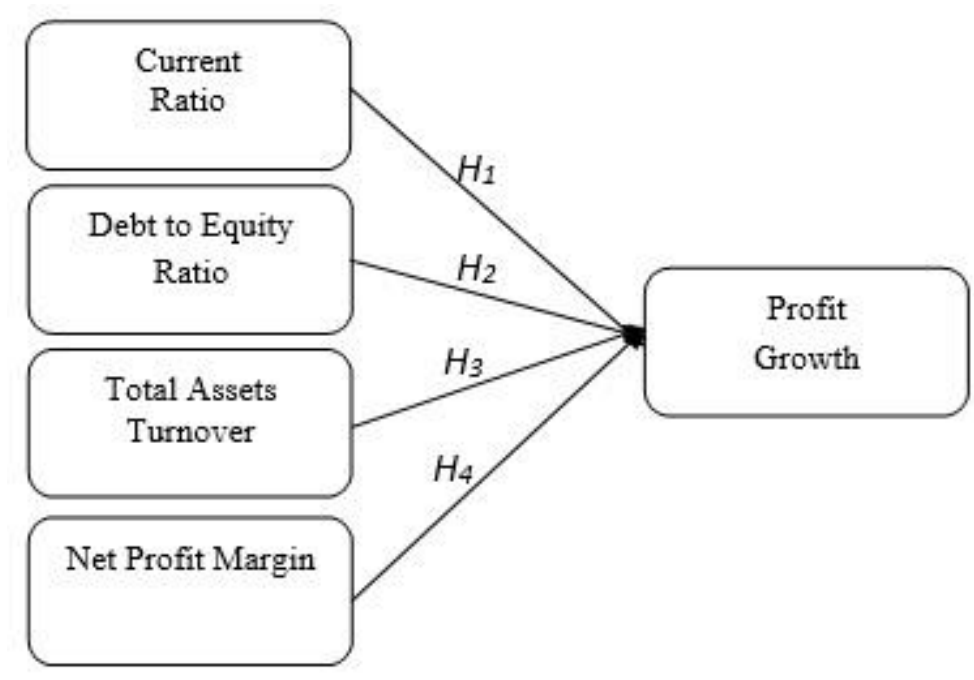


Fig. 1. Component Financial Ratio Planning

Table 2. Variabel Operating

\begin{tabular}{|c|c|c|c|}
\hline NO & Variabel & Pengukuran & Skala \\
\hline & Variabel Dependen & & \\
\hline \multirow[t]{2}{*}{1} & $\begin{array}{l}\text { Profit Growth } \\
\text { Source: } \\
\text { (Ifada \& Puspitasari, 2016) }\end{array}$ & $\mathrm{PG}=\frac{\text { Profit }(t)-\text { Profit }(t-1)}{\text { Profit }(t-1)}$ & Skala \\
\hline & Variabel Independen & & \\
\hline 1 & $\begin{array}{l}\text { Current Ratio } \\
\text { Source : (Mahaputra, 2013) }\end{array}$ & $C R=\frac{\text { Curret Asset }}{\text { Current Liability }}$ & Rasio \\
\hline 2 & $\begin{array}{l}\text { Debt To Equity Ratio } \\
\text { Source : (Abidin, 2015) }\end{array}$ & $D E R=\frac{\text { Total Liability }}{\text { Total Equity }}$ & Rasio \\
\hline 3 & $\begin{array}{l}\text { Total Assets Turnover } \\
\text { Sumber : } \quad \text { (Gunawan } \\
\text { \&Wahyuni, 2016) }\end{array}$ & TATO $=\frac{\text { Net Sales }}{\text { Total Aktiva }}$ & Rasio \\
\hline 4 & $\begin{array}{l}\text { Net Profit Margin } \\
\text { Sumber: (Mahaputra, 2013) }\end{array}$ & $N P M=\frac{\text { Net Profit }}{\text { Sales }}$ & Rasio \\
\hline
\end{tabular}

\subsection{Hypothesis The effect of Current Ratio (CR) in Predicting Profit Growth}

The higher the value of the current ratio, the lower the net income generated by the company. The high current ratio shows the excess of current assets because many current assets are unemployed or are not used in the company's operating activities that generate profits resulting in a low profitability of the company (14). Thus, by knowing the company's current ratio, the easier it is to find out the possibility of lending by creditors, the easier it is to estimate the smooth running of company activities so that current ratios can help predict company profits.

$\mathrm{H}_{1}$ : Current Ratio (CR) has positive influence in predicting profit growth.

\subsection{Hypothesis The Effect of Debt to Equity Ratio (DER) in Predicting Profit Growth}

The greater the debt to equity ratio shows that the capital structure uses more liabilities than equity. That is, the greater the debt to equity ratio reflects the lower solvency of the company so that the company's ability to pay liabilities is low. The amount of liabilities contained in the company's capital structure is very important to understand the balance between the risks and profits obtained. Lability carries risks because each liability in general will cause a permanent attachment to the company in the form of an obligation to pay interest expenses along with installments of its principal obligations periodically (14).

$\mathrm{H}_{2}$ : Debt to Equity Ratio (DER) has positive influence in predicting profit growth.

\subsection{Hypothesis The Effect of Total Assets Turnover (TATO) in Predicting Profit Growth}

The total asset turnover ratio measures the activity and ability of the company to generate sales through the use of assets owned. This ratio can also be used to measure how efficiently 
these assets have been used to earn income so that this ratio can be used to predict future profits (14). The effect of the ratio of Total Assets Turnover (TATO) to the company's growth prediction is the faster the rate of turnover of assets, the net income generated will increase, because the company can utilize these assets to increase sales which affect income (15).

$\mathrm{H}_{3}$ : Total Assets Turnover (TATO) has positive influence in predicting profit growth

\subsection{Hypothesis The Effect of Net Profit Margin (NPM) in Predicting Profit Growth}

Net Profit Margin calculates the extent to which a company's ability to generate earnings after tax at a certain level of sales. This ratio can also be interpreted as the company's ability to reduce costs at the company for a certain period. Low Net Profit Margin indicates sales that are too low for a certain level of cost, or costs that are too high for a certain level of sales, or a combination of both (Kasmir, 2015: 199) (16). Net profit margin (NPM) can be interpreted as a level of company efficiency, namely the extent of the company's ability to reduce costs in the company. The higher the NPM, the more effective a company is in running its operations. The high number of NPM ratios will result in high profits, whereas a low NPM ratio will produce low profits. Thus the high and low NPM will affect earnings predictions. Net profit margin shows the company's ability to generate profits based on net sales so that it has a predictive value in generating profits (15).

$\mathrm{H}_{4}$ : Net Profit Margin (NPM) has positive influence in predicting profit growth.

\subsection{Model}

Data analysis techniques used is multiple regression analysis. The basic model can be formulated as follows:

$\mathrm{Y}=\alpha+\beta 1 \mathrm{CR}+\beta 2 \mathrm{DeR}+\beta 3 \mathrm{TATO}+\beta 4 \mathrm{NPM}+\varepsilon$

\section{Results and Discussion}

Table 3. The Results of Descriptive Statistics

\begin{tabular}{lrrrrr}
\hline \multicolumn{7}{c}{ Descriptive Statistics } \\
\hline CR & $N$ & Minimum & Maximum & \multicolumn{1}{c}{ Mean } & \multicolumn{1}{c}{ Std. Deviation } \\
DER & 72 & .002063 & 8.800967 & 2.37763056 & 1.822117416 \\
TATO & 72 & .073786 & 3.700960 & .82600206 & .570206736 \\
NPM & 72 & .011802 & .649640 & .21664828 & .101293484 \\
$P L$ & 72 & .006462 & 15.092830 & .53725280 & 1.792115739 \\
Valid N (listwise) & 72 & -.894673 & 6.676940 & .13560316 & 1.186808510 \\
\hline
\end{tabular}

Source: Data is processed with SPSS 20

The classic assumption test is the normality test using the non parametrick statistical test Kolmogorov-Smirnov One Sample test. Results Processing data shows data that are normally distributed with a significance level>0.05. Multicollinearity test is done with a matrix by 
looking at the value of VIF (Variance Inflation Factor) and approval value. It can be concluded that the regression model is excluded from multicollinicity between independent variables. Heteroscedasticity test is done by looking at the significance value of the independent variable more than> 0.05. The results of heteroscedasticity test show the significance of three independent variables $>0.05$, it can be concluded that the model does not occur heteroscedasticity. The autocorrelation test by determining the value of Durbin Watson With conclusion $\mathrm{du} \leq \mathrm{dw} \leq 4$-du which is $1,731 \leq 2,110 \leq 2,269$ shows no autocorrelation.

Table 4. Test Results ff the Coefficient of Determination $\mathrm{R}^{2}$

\begin{tabular}{l}
\hline \multicolumn{4}{c}{ Model Summary $^{b}$} \\
\hline Model $R \quad R$ Square Adjusted R Square Std. Error of the Estimate \\
$1 \quad .300^{a} \quad .090$ \\
$\begin{array}{l}\text { a. Predictors: (Constant), NPM, CR, TATO, DER } \\
\text { b. Dependent Variable: } P L\end{array}$
\end{tabular}

Source: Data is processed with SPSS 20

Based on table 3, it can be seen that the value of Adjusted R Square () is 0,324 or $32 \%$. This shows that variations in disclosure of company values $59 \%$ are influenced by independent variables. While the remaining $67.6 \%$ is influenced by other factors outside the model.

Table 5. The Results of Simultaneous Test

\begin{tabular}{|c|c|c|c|c|c|c|}
\hline \multicolumn{7}{|c|}{$A N O V A^{a}$} \\
\hline Model & & Sum of Squares & $D f$ & Mean Square & $F$ & Sig. \\
\hline & Regression & 5.241 & 4 & 1.310 & 8.540 & $.000^{b}$ \\
\hline 1 & Residual & 9.053 & 59 & .153 & & \\
\hline & Total & 14.294 & 63 & & & \\
\hline
\end{tabular}

Source: Data is processed with SPSS 20

Based on table 4 can be seen the results of the $F$ test significance value of 0,000 which means smaller than 0.05 , meaning that the variables current asset, debt to equity ratio, total asset turnover and net profit margin simultaneously influence the profit growth, it can be concluded that this research model can be used to predicting profit growth.

Table 6. The Results of $\mathrm{T}$ Test Statistics

\section{Coefficients $^{a}$}




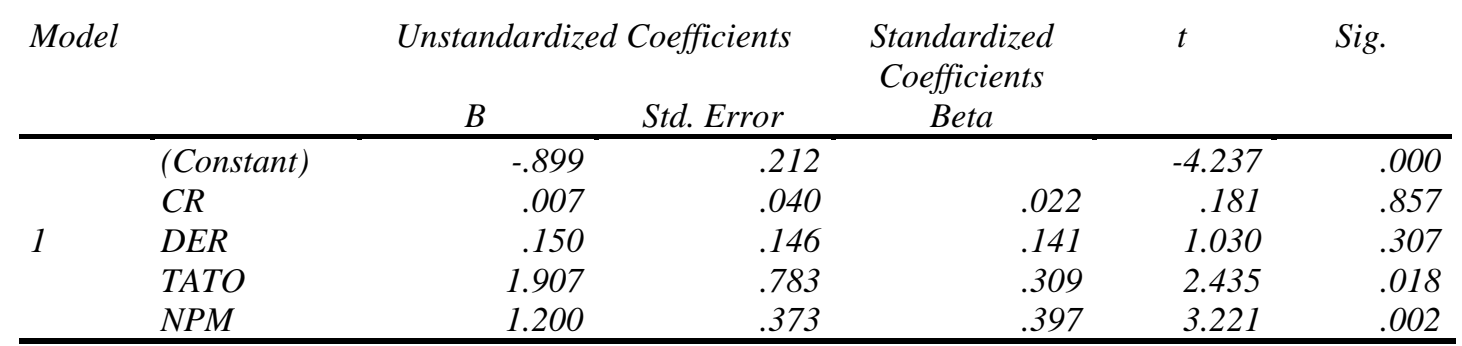

a. Dependent Variable: $P L$

Source: Data is processed with SPSS 20

Based on the results of the $\mathrm{T}$ test it can be seen about current ratio, debt to equity ratio, total assets turnover and the net profit margin having sig. $<0.05$, which means variables that are partial significant to predicting profit growth. Based on processing data from table 4 , the regression equation can be produced as follows:

Multiple Regression Analysis

$y=-0.899+0,007 \mathrm{CR}+0,150 \mathrm{DeR}+1,907 \mathrm{TATO}+1,200 \mathrm{NPM}$

Explain that when there are no variables effect or CR, DeR, TATO and NPM value 0, the profit growth has a value of $-0,899$. If there is a $1 \%$ increase, the CR variable will be followed by an increase in earnings growth $-406,101$. If there is a $1 \%$ increase in the DER variable, it will be followed by an increase in profit growth of 8,603 . If there is an increase of $1 \%$ TATO variable will be followed by an increase in earnings growth 1,907 and If there is an increase of $1 \%$ the NPM variable will be followed by an increase in profit growth of 1,200.

\subsection{Hypothesis Testing The Effect of Current Ratio in Predicting Profit Growth}

The results of the data processing analysis show that Current Ratio (CR) has not significant effect in predicting profit growth. the current ratio shows the level of security of the short-term creditor, or the ability of the company to pay the debts. The company's ability to pay current debts with current assets. Conceptually the current ratio (CR) shows the company's ability to pay short-term financial obligations on time so they can provide good information to prospective investors. This information will affect the increasing interest of investors in investing, which results in increased profits so that profit growth will be corrected with increasing value. Therefore, the current ratio has a positive influence, where the higher the current ratio of a company the higher the profit growth. Conversely, the lower the current ratio of a company, the lower the profit growth. Although the results of this study are not in line with Aprilia and Andayani (2017) (17), the results of this study are in line with the results of the study of Zafira (2016) which states that CR has no effect in predicting earnings growth (5).

\subsection{Hypothesis Testing The Effect of Debt to Equity Ratio in Predicting Profit Growth}

The results of data processing show that the debt to equity ratio (DER) has not significant in predicting corporate profit growth. The higher DER indicates the higher use of debt as a source of corporate funding. Debt to equity ratio can affect profit predictions because funding obtained from third parties (creditors) will be used to fund assets that will be used in 
operational activities to generate profits. The greater the funding obtained from debt, the greater the opportunity for the company to make a profit. In addition, the utilization of corporate debt is also very important. If the company's debt can be utilized properly, the company will be able to create large profits. This is also supported by the research of Purwanto and Bina (2016) (18), Ifada and Puspitasari (2016) and Abidin (2015) that DER has no influence on company profits (14),(7). However, this study disagrees with that of Mahaputra (2013) stating that DER has an influence on profit growth (19).

\subsection{Hypothesis Testing The Effect of Total Assets Turnover in Predicting Profit Growth}

It can be concluded that total assets turnover has a positive effect in predicting profit growth. This can be seen at the maximum TATO value of 0.6496 owned by PT Metropolitan Land Tbk in 2016 which has a profit growth value of 0.3189 while PT Greenwood Sejahtera Tbk in 2017 has a smaller profit growth value of -0.1030 with TATO minimum is 0.0118 . This indicates that the greater the total assets turnover, the more the growth of profit will be. This means that the effectiveness of the management of the company's resources from the total availability of assets is very good, so that the availability of assets owned can increase the company's operational activities, especially in terms of the ability to increase the company's profit growth. It can be assumed that the company's asset turnover in generating profits is very effective, where Total Assets Turnover has a positive influence on Profit Growth. The faster the rate of turnover of assets, the net income generated will increase because the company can utilize assets to increase sales that affect income. Thus the more effective the company's asset turnover or asset management is able to produce high company performance so that it can increase company profits and have an impact on increasing the rate of return (investors). The results of this study are in line with the research conducted by Abidin (2015) (14), Mahaputra (2013) and research from Gunawan and Wahyuni (2014) which states that there is a significant effect of total assets turnover on earnings growth (20),(19). And contrary to Wijaya and Hidayat's research (2015) that no influence between total assets turnover in predicting profit growth (15).

\subsection{Hypothesis Testing The Effect of Total Assets Turnover in Predicting Profit Growth}

The effect of net profit margin on profit growth is because conceptually net profit margin shows the measurement of profit margin on sales, where the net profit margin is getting bigger, the better because it is considered the company's ability to obtain profits is high and will affect profit growth, and vice versa the lower net profit margin, the lower the company's ability to earn profits and will also affect the profit growth of a company. This research is in line with the research of Purwanto and Bina (2016) which suggests that there is a significant effect between the net profit margin on profit growth (18). And this research contradicts the research of Wijaya and Hidayat (2015) which states that the net profit margin does not have a significant effect on profit growth (15).

\section{Conclusion}

Based on the descriptions that have been disclosed in the discussion above, then conclusions can be taken as answers to the main issues raised in this study, namely: 
1. Current Ratio (CR) has no significant positive effect in predicting profit growth. The current ratio shows the company's ability to pay short-term financial obligations on time so they can provide good information to prospective investors. This information will affect the increasing interest of investors in investing, which results in increased profits so that profit growth will be corrected with increasing value.

2. Debt To Equity Ratio (DER) has no effect in predicting earnings growth at. The higher DER indicates the higher use of debt as a source of corporate funding. Debt to equity ratio can affect profit predictions because funding obtained from third parties (creditors) will be used to fund assets that will be used in operational activities to generate profits.

3. Total Assets Turnover (TATO) has a significant positive effect in predicting profit growth in real estate and property companies listed on the Indonesia Stock Exchange with the research period of 2015-2017, the higher the total assets turnover the higher the company's profit growth.

4. Net Profit Margin (NPM) has a significant positive effect in predicting profit growth in real estate and property companies listed on the Indonesia Stock Exchange with the research period of 2015-2017, the higher the net profit margin the higher the company's profit growth.

\section{References}

1. www.finance.detik.com.

2. www.kontan.co.id.

3. Hadiningrat EW, Mangantar M, Pondaag JJ. ANALISIS PENGARUH RASIO LIKUIDITAS DAN RASIO PROFITABILITAS TERHADAP RETURN SAHAM PADA PERUSAHAAN LQ 45. J EMBA J Ris Ekon Manajemen, Bisnis dan Akunt. 2017;5(2).

4. Basrowi dan Juariyah S. Jurnal Ekonomi \& Pendidikan, Volume 7 Nomor 1, April 2010. J Ekon Pendidik. 2010;7(April):58-81.

5. Zafira N. Analisis Rasio Likuiditas, Rasio Leverage, dan Rasio Profitabilitas terhadap Perubahan Laba. J Ilmu dan Ris Akunt. 2016;2(9).

6. Michael S. Job market signaling. Q J Econ. 1973;87(3):355-74.

7. Ifada LM, Puspitasari T. Analisis pengaruh rasio keuangan terhadap perubahan laba. J Akunt dan Audit. 2016;13(1):97-108.

8. Harahap SS. Teori Akuntansi, Edisi Revisi, Cetakan Kelima, PT." Raja Grafindo Perseda, Jakarta. Terjemahan. Edisi Ketujuh. Jakarta: Penerbit Salemba Empat. 2011.

9. Khadafi M, Heikal M, Ummah A. Influence analysis of return on assets (ROA), return on equity (ROE), net profit margin (NPM), debt to equity ratio (DER), and current ratio (CR), against corporate profit growth in automotive in Indonesia Stock Exchange. Int J Acad Res Bus Soc Sci. 2014;4(12).

10. Brigham EF, Houston JF. Dasar-Dasar Manajemen Keuangan (Essentials of Financial Management)." Jakarta: Salemba Empat. 2010.

11. Hanafi MM, Halim A. Analisis Laporan Keuangan, Edisi Keempat." Yogyakarta: UPP STIM YKPN. 2009.

12. Zulkifli Z. Pengaruh Current Ratio, Debt To Equity Ratio Dan Net Profit Margin 
Terhadap Earning Growth Pada Perusahaan Pertambangan Yang Tercatat Di Bursa Efek Indonesia. J Ekon. 2018;23(2).

13. Minanari M. Pengaruh Profitabilitas, Manajemen Laba dan Kebijakan Deviden terhadap Nilai Perusahaan (Studi Empiris pada Perusahaan Manufaktur yang Terdaftar di Bursa Efek Indonesia Periode 2015-2016). Profita. 2018;11(1):139-49.

14. Abidin Z, Asyik NF. Pengaruh Rasio Keuangan Terhadap Perubahan Laba Pada Perusahaan Yang Go Public Di Bursa Efek Indonesia. J Ilmu Ris Akunt. 2013;2(5).

15. Wijaya EY, Hidayat B. Analisia Rasio Keuangan dalam Memprediksi Perubahan Laba pada Perusahaan Real Estate dan Property di Bursa Efek Indonesia (Bei). None. 2015;2(1).

16. Kasmir. Analisis Laporan Keuangan. PT. Rajagrafindo Persada. Jakarta. 2015.

17. Handayani AT, Nugroho B. Dampak Rasio Keuangan terhadap Perubahan Laba pada Perusahaan Makanan dan Minuman. J Online Insa Akuntan. 2018;3(1):39-48.

18. Risa BC. Analysis of Financial Ratio towards Earning Growth in Mining Companies. Univers J Ind Bus Manag. 2016;4(3):81-7.

19. Mahaputra INKA. Pengaruh Rasio-Rasio Keuangan Terhadap Pertumbuhan Laba Pada Perusahaan Manufaktur Yang Terdaftar Di BEI. J Ilm Akunt dan Bisnis. 2012;

20. Gunawan A, Wahyuni SF. Pengaruh rasio keuangan terhadap pertumbuhan laba pada perusahaan perdagangan di Indonesia. J Ilm Manaj dan Bisnis. 2014;13(1). 